\title{
CHALLENGING TRADITIONAL MARRIAGE LAWS IN THE DUCHESS OF MALFI: LOVE OR LONGINGS OR DEFYING PATRIARCHY?
}

\author{
Anasuya Adhikari ${ }^{1}$, Dr. Birbal Saha ${ }^{2}$ * \\ ${ }^{1}$ Research Scholar, \\ $2^{2 *}$ Professor, Department of Education, Sidho-Kanho-Birsha University, Purulia, West Bengal, India
}

"Corresponding Author: Dr. Birbal Saha

Article DOI: https://doi.org/10.36713/epra8937

DOI No: 10.36713/epra8937

\begin{abstract}
The Duchess of Malfi by John Webster speculates into the tradition of Elizabethan marriage, laws regarding marriage, its violation and the consequences it brings. The drama continues to reverberate among today's audiences because of the majestic appeal of the Duchess and her enterprising tryst at rebuffing the 'authority of social conventions and norms'. The Duchess has been credited for her attempt and bravery to choose and win over a spouse for love. Wedding, one of the most important moment of a woman's life, was seen from a completely different perspective, temperament and in a 'nonsecular' impression. The woman during the Elizabethan age had absolutely no choice in selecting her prospective groom. Women were seen subservient to men. Elizabethan woman were raised to believe that they were inferior to men and that they must abide by 'the other's verdicts'. Disobedience was a crime against religion and the consequences were monstrous. Webster uses majestic traits to exemplify the Duchess' feminine strength of virtuosity and greatness which instil in the modern audience's empathy and respect for the Duchess. This paper tries to revisit The Duchess of Malfi, decoding these socio-cultural and religious perspective and the ways of the aristocracy used by Webster, contributing to the eventual downfall of the Duchess. This paper also delves deep into documenting Webster's attempt to portrays her as a tragic heroine and victim of law.
\end{abstract}

KEYWORDS: The Duchess of Malfi, John Webster, Elizabethan marriage laws, Violation of laws, Tragedy

\section{INTRODUCTION}

When one takes the perspective of the whole tragic tradition, it becomes quite important that tragedy does alter its shape and meaning from one century to the other with chameleon variability. Aristotle defined tragedy in his Poetics as:

"The imitation of an action that is serious and also, as having magnitude, complete in itself; in language with pleasurable accessories, each kind brought in separately in the parts of the work; in a dramatic, not in a narrative form; with incidents arousing pity and fear, wherewith to accomplish its catharsis of such emotions.",

No tragedy is simply a cry of pain. Webster's The Duchess of Malfi, a Jacobean revenge tragedy, is an apprehension of pain in relation to a senseperhaps bleak, perhaps consolatory-of what it is to be human. The Duchess falls a prey to the catastrophe by stepping out of societal expectations as well as traditional restrictions. According to Bogard, "It is true that Webster makes use of traditional standards of moral evaluation in delineating his character. But for him, these standards shift alarmingly: the usual distinctions between good and evil become inadequate for a true picture of life and are finally passed over. Man's world as Webster sees it, is a deep pit of darkness, and mankind is 'womanish and fearful'..."

Webster explicitly renders the gravity of the theme of marriage in The Duchess of Malfi. The tragedy debuts estimable speeches haunting upon the rudimentary delights of conjugal life. The play targets a specific political meaning and apparently inconsequential speeches are precipitously ignored. Antonio and Cariola's conversation can be the finest example of such a matter, which situations itself in the Duchess' bed-chamber, shortly before the obtrusion of Ferdinand. 
"Antonio: When wilt thou marry, Cariola?

Cariola: Never, my lord.

Antonio: O fie upon this single life: forgo it:

We read how Daphne, for her peevish flight,

Became a fruitless bay-tree; [...] Whereas those

Which marry'd, or prov'd kind unto their friends,

Were, by a gracious influence, transshap'd

In to the olive, pomegranate, mulberry,

Became flowe's, precious stones, or eminent stars." (III. ii.)

This admonition, echoing the Renaissance vision of breeding, Cariola discounts consciously as 'Vain Poetry'. The colloquy produces an impact of an effervescent obscenity leaped into by the wooing lovers cloistered in the ultimate privacy of the bedchamber. The heavenly moment is soon concluded with proceedings of major, serious and thoughtful import claiming our attention. Noticeably, Antonio's tribute, paid to the state of conjugality reflects astonishingly the view of Puritanism, much sovereign from the Catholic views of glorifying chastity. Dusinberre's pens down the 'alignment of the dramatist with the middle-class' focus to ignore the pressure of the conflicts, incompatibility, of the viewpoints nourished simultaneously by a significant number of contemporary people.

The contradiction, we are about to encounter with in the succeeding pages, finds relevance and kinship to our study of 'The Duchess of Malfi', claiming diverse interpretations since ages. The protagonist over and over has been assessed, as Webster's contemporaries have presumed to have concluded her actions, looking after the prevalent traditional orthodoxies. The 'courage' can be interpreted by some as a sign of reckless individualism while it might appear to others as positively life-affirming. A major part of the remaining portion of this paper will contemplate on the Wooing Scene of the 'The Duchess of Malfi'; and, at the same time, will also focus onto the marriagecontract that succeeds the wooing. The Duchess audaciously declares the marriage as 'espousal per verba de presenti' and to be complete in itself. She envisioned a self-fulfilment in the act.

\section{THE DEPICTION OF MARRIAGEIN THE PLAY}

William Painter in his 'Palace of Pleasure', makes the act of the Duchess' remarriage a subject of 'true' moral ignominy, a "curs'd example",

"Beholde here (O ye foolish lovers) a Glasse of your lightnesse, and ye women the course of your fonde behaviour [...] shall $I$ be of the opinion that a household servant ought to sollicite, nay rather suborne the daughter of his lord without punishment or rather a vile and abject person dare to mount upon a Prince's bed?" (qtd. Jardine 91)
Painter speaks adversely of how Antonio, the steward was lured by the Duchess into a secret marriage. John Webster, telescopes the intermediary stages, in his version, covering the courtship and subsequent marriage with Antonio in a single scene, fixating on a woman's initiatory self-battle and triggering her part to make the 'marriage' possible. Throughout the play, the Duchess is seen to be continuously defying the patriarchal authority and continuously asserting her own agency not only for the sake of her children but also for the sake of her love and self-interest. The Duchess' remarriage has been a prima facie and is been often rationalized in terms of a natural human longing to felicitate domestic existence.

"Duchess: What do you think of marriage? Antonio: I take't, as those that deny purgatory, It locally contains or heaven, or hell;

There's no third place in't.

Duchess: How do you effect it?

Antonio: My banishment, feeding my melancholy would often reason thus:

Duchess: Pray let's hear it,

Antonio: Say a man never marry, nor have children, What takes that from him? Only the bare name Of being a father..." (I. ii)

Marriage is part of a "total social system, and is always tied into economic and political arrangements" (Hall 123). Antonio chronicles marriage as a communion, the 'first good deed [...] After man's creation.' The Duchess' concern about the predicament was a much $17^{\text {th }}$ Century belief of the preachers, who were never exasperated repeating before the congregation about what might be laid up for her in heaven- 'domestic felicity in the world below was a sight pleasing in the eyes of God' (Wright 215). The lovers' words, stirred with a sense of piety, seemingly established an alternative angle of vision pertaining to their marriage. According to some critics, Webster had an intension to denounce the Duchess' marriage. But if it was so, Webster would have taken a judgemental stance, adopting the context of an ancient notion, a much stubborn orthodox stance.

The Duchess is, of course not breaching the purported norms of femininity at the end of Act 1 by unveiling prominent role in the marriage, and concurrently in courting and thusly marriage proposal to Antonio. She exposes to be even audacious than Shakeapeare's Desdemona, who is acquiesce to hint Othello of her welcoming courtship. But the Duchess does this not just for the call of her libido. Indeed, she speaks of sexuality with admirable common sense in her speech to Antonio: "This is flesh and blood, sir, / 'Tis not the figure cut in alabaster / Kneels at my husband's tomb' (1.1.457-9)". Later on, in the 
moment of great danger, she asks Ferdinand: “"Why should only I / Of all the other princes of the world I Be cased up like a holy relic? I have youth, / And a little beauty' (3.2.137-9)." Both these passages stress the difference between nature and artifice, between the naturalness of a woman's flesh, blood, youth and beauty and the way patriarchal society seeks to transform women into decorative, precious objects that can be locked away and safely controlled. The Duchess' expression of her own sexuality is in a demeanour that makes it sound healthy and natural, but is in complete opposition to a patriarchal mindset predisposed in seeing women in terms of the binary oppositions of angel and whore.

\section{THE SINS OF THE DUCHESS}

The Arragonian brothers' antipathy for the carnal nature of their sister has been marked by a number of critics, who possess prejudiced thought of being guilty of a 'moral infraction the gravity of which charm fails to dissipate' (Calderwood 107). She is found deficient and deviated from the "political and moral exemplar', which is a must-have quality of a duchess. The Duchess is engulfed in a three-fold sin-that she marries disrespecting the so called societalstature of a widow; she descends the hierarchy to marry beneath her rank; and most importantly denies to lend an ear to the timely cautions of her brothers. The Duke and the Cardinal epitomize the binary powers of the State and the Church that the Duchess has at first clandestinely and following it, openly, rebuffed. The thoughts of the contemporary audience of Webster is here brought under clarity by the critics. In doing this what exactly has not earned much demanding attention is the implication of the stand endorsed by the Duchess, on a notion that cautioned, during the days of Webster, strides into theological confusion. The connubial in the tragedy was likely to have been hailed with a diverse response. Similarly, the image of a woman describing her bond as an 'absolute marriage' ought to have been scrutinised with a sensibility compounded amicably with horror and admiration. Webster's audience confronted a woman in the Duchess who was at no time apologetic for the act of relentlessness and encountered the fate of her action with an equanimity, not possessed by many contemporary tragic heroines.

The circumstances in which the Duchess marries Antonio are not the same as compared to the other tragic heroines like, Clare in George Wilkins 'The Miseries of Enforced Marriage' (1605-07) and Panthea in Ford's 'The Broken Heart' (1625-33), who suffered similar lot as the Duchess. The women characters are found struck mercilessly between the 'world's opinion' and the 'heart's desire'. The brother-characters, may it be Ithocles or the Arragonian brothers, neither of them think much of their sister's secret marriage, skipping the official and the social ceremony. It must, however be added that this insensitivity was largely endemic in popular culture and can be partly accounted for by an inconsistency inherent in the existing marriage laws. We can take a look into the following laws related to marriage for a sound understanding.

There is an attempt from the Duchess where she utilizes her socio-religious customs performed throughout her wedding. She manages Antonio to breach a cultural taboo. It is evident from Antonio's speeches which interrupts the Duchess frequently that he was not well equipped to fight both- the unconventionality of the relationship and the courtly intrigues. Thus, Cariola fears about the Duchess, "Whether the spirit of greatness or of woman / Reign most in her, I know not, but it shows / A fearful madness. I owe her much pity" (Act I, Scene I. p.505507) - "foreshadow the results of her daring attempt to establish a private sphere in which her class does not dictate her actions. Ferdinand and the Cardinal exploit their power to undermine the Duchess." (Prendergast, 2007)

\section{ELIZABETHAN MARRIAGE LAWS AND THE AUTHORITY OF THE CHURCH}

Since the $12^{\text {th }}$ Century, the medieval church played a dominating role in enclosing and diverting its folks from being promiscuous, and termed espousal per verba de present as a valid marriage. Espousal per verba de present was a declaration signed by both the man and woman to achieve a title of being husband and wife legally married. No third party witness was essential in the declaration made in any secret spot to gain its legitimacy. The contract, nonetheless, was binding, with no priest to offer his blessings, and could not be breached by either of the two partners, without committing the sin of adultery in the process.

As Henry Swinburne, whose Treatise on Spousals (written c.1600) is one of the most reliable sources of information about the Elizabethan marriage laws, puts it,

"albit there be no witness of contract, yet the Parties having verily (though secretly) Contracted Matrimony, they are very Man and Wife, before God." (Quoted Schanzer 83)

With all escape- routes mysteriously sealed, the couples, however, found themselves in the contradictory position of being clinched in an emotional bond that remained surreptitious until the church put its official approval on it. It was rebellious. It was defying the Catholic Church and tradition. The Duchess parodies the ceremonial aspects throughout her impromptu wedding ceremony in order to preserve authenticity for her deed. She inevitably takes the role of the Priest to establish her love in terms of a social institution. "Poets like 
Shakespeare, Webster, and Chaucer can, if they wish, enlist us on the side of their victims by confronting us with cosmic and social injustices so cruel, so extreme, that we cannot but join in the protest against them. Therefore, to assert that Webster's Duchess deserved torture and death because she chose to marry the man she loved and to bear his children is, in effect, to join forces with her tyrannical brothers, and so to confuse the operation of some poetic justice, of which we should approve, with precisely those examples of social injustice which Webster does everything in his powers to make us condemn" (Hawkins, 1975).

It is quite evident from here that the aristocratic women rarely had the privilege to choose their spouse. Hence, unless and until the approval of the church was received, the marriage could not be consummated. The contradiction, so glaring that, while the lovers get seized into a confusing scenario where they are regarding and respecting a bond and forged into a genuine spirit of amity and mutual trust, as sacred, while others dismissing it as unholy and spurious. To those who supposed espousal per verba de presenti to be an end in itself, the Church had to say this by way of warning, "If that Man and Woman or theyr proctours do make matrimony secretly by themselves without any record or but with one witness that is called matrimony clandestine at the which for many causes is forbidden by law." (Quoted Schanzer 83)

There is an attempt from the Duchess to create an insular world, where the society, the church or the Royalty would not be able to interfere. But it is found that a noticeable act by Antonio when he warns the Duchess of inviting devils through their deeds. The marriage ends lamentably since it was the Duchess' miscalculation which makes her literally knot in dealing with her private domain being a public figure. The Duchess's rejected the feudalism predominant in case of the arranged marriages in the aristocracy, which created a dicey arena for them.

\section{ANTONIO'S IMPRESSION OF THE DUCHESS}

In The Duchess of Malfi, the Duchess and Antonio marry, not behind the stage, but in full view of the audience. There is an acute consciousness on the part of the Duchess looking after the apocalyptic implication of a remarriage. The choice has been determined. Webster has been at pains to make clear, by her deep regard for the moral transparency of the steward, whose timidity, however, is a stumbling block that she must strive to surmount. The initiative resided in the Duchess and on Antonio's part, he remained more of steward than a lover does, is merely a compliance.

Antonio is fascinated by the show of firmness, as he confronts it somewhere he was least expecting to find it- in a woman, the Duchess. His tribute to the
Duchess, earlier on, did not include courage among the virtues he claimed to have discerned in her. Different from her brothers, 'cast in one figure of so different temper' she was represented there as a woman engrossing in her speech and with a stamina to 'raise one to a galliard' but with one sweet look. Her demeanour is divine and gratuitous from all the bawdy thought. The Duchess, in a nutshell, might serve as an epitome of virtue for every other woman.

\section{THE CHILDREN BEGOT FROM THE WEDLOCK}

Ferdinand epitomizes the Duchess' children begot from her second marriage as 'bastards'. While Ferdinand's calling them 'cubs' is emblematic of a disease, gradually takes occupancy of his mind. He keeps on addressing them as 'bastards' (IV. i. 36) even after the Duchess' acknowledgement of her remarriage, makes her quite adamant to say- 'will you see my husband? (III. ii. 87). This also at par suggests an unwillingness, on Ferdinand's part to recognise and accept the validity of a marriage consummated without his approval. The text records the Duchess not only laying claim to the legitimacy of her children but at the same time defending the marriage itself along conspicuous orthodox lines,

"You violate a sacrament o 'th' church

Shall make you howl in hell for 't." (IV. i. 39-40)

The impertinence involved in soliciting to fob off a marriage executed with limited or no regard for the sacramental church laws as staggering. But it seemed to be a mere bluff which was aimed to mute a protesting brother turns out to be evident, as the Duchess assures her husband with words of profound religious conviction,

"In the eternal Church, Sir

I do hope we shall not part thus." (III. v. 71-72)

\section{THE WOOING SCENE}

Returning to the ethereal Wooing Scene, though hesitant and shy at first, the Duchess soon woes Antonio candidly. She consciously brushes aside the speculations which might have forewarned about her brothers, their misgivings and objections. She credits those as inconsequential. She steadily discards the 'ceremonial importance' and executes what James L. Calderwood has penned as the 'ritual gesture' of marriage (Calderwood 109). She is quite aware of what consequences she might draw and her consciousness issues a statement:

\section{"I have heard lawyers say, a contract in a chamber} Per verba de presenti is absolute marriage." (478-79)

The heaven's blessings is sought to safeguard a bond, she herself considers to be inviolate, against all possible outbreak of violence. There is a tone of marked decision in her remark about the Church's 
supposed authority to confer validity upon a clandestine marriage.

"We are now man and wife, and 'tis the Church

That must but echo this." (491-93)

The next step was crucial and an infringement upon the marriage laws was to consummate the marriage. She was though unaware of the terrible fortune she was inviting both for Antonio and herself. We come to know in the very next scene when Bosola declares that the Duchess 'Is sick a-days, she pukes, her stomach seethes'. The presence of a witness was never thought to be essential for secret connubial, Cariola's presence in this scene is to provide the audience reaction of the theatre, sitting invisible in the darkness.

\section{SIMILARITY WITH PRESENT TIME- A STUDY OF SOCIAL}

The theme binds congruity with Arundhati Roy's The God of Small Things (1997), spiriting a novel of contemporary times, even bears strategically analogous areas of conflicts. The conflicts can be cogitated under the concepts of Feminism, which is socio-political in The Duchess of Malfi, while domestic and social in The God of Small Things. Even though millennium surmounted since the age of the Elizabethans to the contemporary times, with women outshining into omnifarious regimes and arena of personal and public domains, it is conspicuous that women are yet to actualize the place of utmost importance in the patriarchal society. Representation of women in politics is yet marginal, disapproval of self-chosen marriages are prevalent, while violence and honour killings are becoming a growing attempt in our society. Therefore, these approve to be the societal issue of the present times in India, which is even envisaged by Arundhati Roy, and is very much at par with the plight of the Duchess. The two female protagonists of Roy and Webster, though belonging from two contrasting times, different continents, disparate societies and under differing political (governmental) set-ups, are interestingly, very much alike and bears a testimony to the female oppression, even millenniums apart.

\section{CONCLUSION}

The extent and intensity to which society in the Elizabethan age was thought to bear the impact of trivial acts of instability on the part of its representatives can be judged from a pamphlet published in 1589 by Sir John Stockwood. It was entitled 'A Bartholonew Fairing for parents [...] shewing that children are not to marry without the consent of their parents, in whose power and choice it lieth to provide wives and husbands for their sons and daughters.' It even elaborated that the outbreak of the Plague as 'a judgement sent by God on account of the prevalent disobedience of children' (Wright 208).
Elizabethan age was such a time when the language of power was inextricably bound up with that of religion, no marriage could actually be 'absolutely secular' and even a marriage involving a petty act of disobedience could be seen as potentially disastrous. Webster's The Duchess of Malfi helps in the expansion of the tragic burden, and at the same time marks a time when marriage outside the papal consent could bring apocalypse, which was not only non-secular but hateful, brutal and inhumane dominating the extreme womanly urge of a serene home.

\section{REFERENCES}

1. Adhikari, A. and Saha, B. Demystifying Social Taboos in Indian Milieu: A Critical Study on Arundhati Roy's 'The God of Small Things', International Journal of Multidisciplinary Educational Research, Vol. 10, Issue. 3(4), 2021, p. 151-155

2. Adhikari, A. and Saha, B. Women Participations in Education and Politics: A Twenty First Century Scenario, International Journal of Research in Social Sciences, Vol. 11 Issue 04, 2021, p. 68-74

3. Adhikari, A. and Saha, B. Self-Nested Prison of Constraints: Feminism, Theory, Praxis and Beyond, International Journal of Research in Social Sciences, Vol. 11 Issue 08, 2021, p.46-58.

4. Belton, E.R. The Function of Antonio in The Duchess of Malfi, Texas Studies in Literature and Language, Vol. 18, No. 3, An Issue Devoted to the English Renaissance, (FALL 1976), pp. 474-485.

5. Boklund, G. The Duchess of Malfi: Sources, Themes, Characters. Cambridge: Harvard University Press, 1962.

6. Calderwood, James L. The Duchess of Malfi: Styles ceremony in Webster. The White Devil and The Duchess of Malfi: A casebook, Ed. R.V, Holdsworth, London: Macmillan 1975.

7. Cave, R.A. Text and Performance, The White Devil and The Duchess of Malfi, Macmillan Education, 1988.

8. Cuddon, J.A. The Penguin Dictionary of Literary Terms and Literary Theory, Penguin Books, 1998.

9. Doebler, B.A. Continuity in the Art of Dying: The Duchess of Malfi," Comparative Drama, Vol. 14, No. 3 (Fall 1980), pp. 203-215.

10. Fieler, F.B. The Eight Madmen in The Duchess of Malfi, Studies in English Literature, 1500-1900, Vol. 7 , No. 2, Elizabethan and Jacobean Drama (Spring, 1967), pp. 343-350.

11. Hawkins, H. The Victim's Side: Chaucer's Clerk's Tale" and Webster's Duchess of Malfi," Signs, Vol. 1, No. 2 (Winter, 1975), pp. 339-361.

12. Hall, Kim F. Things of Darkness: Economies of Race and Gender in Early Modern England. Ithaca, NY: Cornell University Press, 1995.

13. Henderson, A. Death on the Stage, Death of the Stage: The Antitheatricality of The Duchess of Malfi," Theatre Journal, Vol. 42, No. 2 (May, 1990), pp. 194-207.

14. Jardine Lisa, Still Harping on Daughters: Women and Drama in the age of Shakespeare, Sussex: The Harvester Press, 1983. 
15. Kistner, A. L. \& Kistner, M. K. The big sleep: Expectation and delusion in the duchess of Malfi, Department of English, University of Colorado, Published online: 21 Jul 2008

16. Levy, M. The Duchess of Malfi Revisited: J. R. Dunn's Science Fiction Revenge Tragedy, Extrapolation, The University of Texas at Brownsville and Texas Southmost College, Vol. 43, No. 4, 2002.

17. Lifson, M.R. Embodied Morality in The Duchess of Malfi," Pacific Coast Philology, Vol. 23, No. 1/2 (Nov., 1988), pp. 47-59.

18. Luckyj, C. The Duchess of Malfi: A Critical Guide, Continuum International Publishing Group, 2011.

19. Luckyj, C.Great Women of Pleasure." Main Plot and Subplot in The Duchess of Malfi, Studies in English Literature, 1500-1900, Vol. 27, No. 2, 1987.

20. Male, D. The White Devil and The Duchess of Malfi by John Webster, Macmillan Master Guides, 1986

21. Miller, W.C. Macabre Vitality: Texture and Resonance in The Duchess of Malfi, Renaissance Drama, Vol. 43, No. 2 (Fall 2015), pp. 193-216

22. Nicoll, Allardyce. British Drama: An Historical Survey from the Beginnings to the present time. Doaba House, Delhi, Fifth Edition

23. Oakes, E. The Duchess of Malfi"as a Tragedy of Identity, Studies in Philology, Vol. 96, No. 1 (Winter, 1999), pp. 51-67

24. Prendergast, M. A. The Duchess' 'New World': Marriage and its consequences in The Duchess of Malfi, A Thesis Submitted to the University of North Carolina Wilmington in Partial Fulfillment of the Requirements for the Degree of Master of Arts, Department of English University of North Carolina Wilmington.

25. Roberts, J.A, Woman and Gender in Renaissance Tragedy: A Study of King Lear," Othello," The Duchess of Malfi," and The White Devil." by Dympna Callaghan, Shakespeare Quarterly, Vol. 42, No. 2 (Summer, 1991), pp. 236-237

26. Wadsworth, F.W. Webster's Duchess of Malfi in the Light of Some Contemporary Ideas on Marriage and Remarriage. Wadsworth, Frank $W$ Philological Quarterly; Jan 1, 1956; 35, Periodicals Archive Online pg. 394

27. Whigham, F. Sexual and Social Mobility in The Duchess of Malfi, PMLA, Vol. 100, No. 2 (Mar., 1985), pp. 167-186

28. Wright, L.B. Middleclass Culture in Elizabethan England, Chapel Hill: The University of North Carolina Press, 1935

\section{All the lines of the drama, quoted from}

- The Duchess of Malfi by John Russell Brown's edition of the play (London: Methuen \& Co. Ltd., 1964) 